\title{
On Ups and Downs of Chinese Cultural Confidence
}

\author{
Guiying Zhou ${ }^{1}$ \\ ${ }^{1}$ School of Economics and Management, Zhengzhou University of Light Industry, Zhengzhou, China \\ Correspondence: Guiying Zhou, School of Economics and Management, Zhengzhou University of Light \\ Industry, No. 5 Dongfeng Road, Zhengzhou 450002, China. E-mail: zhgy95@126.com
}

Received: February 11, 2012 Accepted: March 9, 2012 Online Published: July 1, 2012

doi:10.5539/ach.v4n2p140

URL: http://dx.doi.org/10.5539/ach.v4n2p140

\begin{abstract}
Chinese nationality has experienced ups and downs in its cultural confidence with the nation's rise and fall. China has become the world's second largest economy and its cultural confidence should be enhanced so that China's soft power will be strengthened too. Chinese cultural confidence can be restored by taking the following three measures: to improve cultural awareness, to understand and rethink traditional Chinese culture deeply and to deal with the relationship between Chinese culture and western culture properly.
\end{abstract}

Keywords: ups and downs, Chinese cultural confidence, Chinese cultural awareness

\section{Introduction and Literature Review}

China has surpassed Japan and become the world's second largest economy. Even during the international financial crisis, Chinese economy kept steady and fast growth despite a downturn of the world economy. Despite China's economic miracles outshining other countries and the remarkable cultural and ideological progress it has made, China faces unprecedented challenges in the field of culture. If China wants to grow up to be a real power and enhance its comprehensive competitiveness, its culture should be more influential, be accepted by the world, and gain the right of speech in the world culture. Nowadays, culture is an important part of the country's comprehensive competitiveness, and it is increasingly becoming a key source of national cohesion and creativity, and a key pillar for economic and social development. China is feeling the urgency of enhancing its soft power and cultural confidence is the key to improve a nation's cultural soft power. Unfortunately, Chinese nationality lacks cultural confidence due to various historical reasons. So the statement issued by the Sixth Plenary Session of the 17th CPC Central Committee, convened in Beijing on Oct.15 to 18, 2011, points out that "In order to construct a socialist cultural power, high cultural awareness and cultural confidence must be improved, civilized qualities of the whole nationality must be enhanced, and the nation's cultural soft power should be strengthened ...." Obviously, enhancement of Chinese cultural confidence and cultural awareness is emphasized from the level of the nation's development.

Cultural confidence has been frequently mentioned in China in recent years. Shan Yun gave it a definition: "cultural confidence means a country, a nation and a political party fully confirming the value of their own culture and having a firm faith in the vitality of their own culture."(Yun, 2011:11) Cultural confidence is the key factor for China to realize the objective of a cultural soft power. Chengxiang Zhong holds that only cultural confidence can make China achieve cultural self-empowerment. (Zhong, 2011:49) In addition, many scholars put forward some proposals about how to improve Chinese cultural confidence. Zhenji Du argues that Chinese nationality can improve its cultural confidence only if it gets rid of both cultural inferiority and cultural arrogance. (Du, 2011:18) Jing Yang maintains that China must enhance its cultural confidence on the basis of cultural introspection in order to make Chinese culture more influential to the world. (Yang, 2010:132) In short, cultural confidence is a hot topic in China.

Cultural confidence is relative to cultural diffidence or cultural inferiority. Chinese nationality has experienced ups and downs in its cultural confidence with the nation's rise and fall. Fortunately, its cultural confidence has been recovering with China's economic development and improvement of people's living standard. 


\section{Ups and Downs of Chinese Cultural Confidence}

\subsection{From Cultural Self-esteem to Full Confidence in Culture}

China, as one of the four ancient civilizations, was undoubtedly in a leading position in human history. By the $16^{\text {th }}$ century, China had been a nation with strong comprehensive national strength, and its economic aggregate accounted for 23\% of the world's total. (Xu, 2010:52)It had also been the center in the civilization of eastern Asia. Its Confucianism-oriented culture, which was formed based on the Han nationality, had been influencing the social progress of surrounding nations and regarded as the best culture in the world and superior to that of other minorities and other nationalities in the world. At that time, China deemed itself as a celestial empire and Chinese people were very self-confident in their culture and had a strong superiority complex. They believed that those uncivilized and savage nationalities should learn from them and pay respect to their country, which, in return for that, would regard them as tributaries and keep an eye on them as a special favor. In short, China considered itself as the center of the world civilization with its culture radiating around and bringing about gospel to the world.

\subsection{From Cultural Confidence to Self-conceit}

From the $16^{\text {th }}$ to $18^{\text {th }}$ century, China was in its summit of feudalism society and was in the leading position in many fields such as politics, philosophy, and science technology and so on. It not only enjoyed a high prestige in Asia, but also played an important role in the world. It had been spreading its culture, technology and various products to western countries. Chinese still considered Confucianism as the best culture. In addition, Chinese people's scanty knowledge about geography resulted in an illusion that China was the center of the world's civilization.

In 1583, an Italian missionary of Christianity named Matteo Ricci came to China to do his missionary work. However, China, as a big country with several thousand years of history, still had the self-conceited cultural psychology and its people, who were quite mature in their cultural psychology and had an antitheism tendency, showed little enthusiasm for that. Therefore, it was difficult for Christianity to take root in China at the very beginning. In order to do their missionary work efficiently, missionaries began to learn Chinese, take Chinese names, wear Chinese clothes, read Confucian classics and accept Confucian thoughts, which made Chinese people more conceited. In addition, they introduced advanced technology to attract Chinese, who were not quite familiar with them. Accordingly, western learning such as astronomy, calendar-study, mathematics, geography, physics, mechanical engineering, artillery-making technology and so on was spread in China.

Furthermore, western merchants who came to China to do business at the early stage were willing to act servilely or obsequiously in order to reap fabulous profits, which also strengthened Chinese arrogance to some extent. In the $16^{\text {th }}$ and $17^{\text {th }}$ centuries, merchants mainly came from small western countries such as Portugal, Spain and Netherlands, which were not the representatives of Industrial Revolution. Therefore, faced with China, comparatively a power at that time, these small countries were not strong enough to launch a war and they could not but give in. Therefore, it was not strange that Chinese people had strong superiority complex and were self-conceited at that time.

\subsection{From Self-conceit to Loss of Confidence}

Before the $16^{\text {th }}$ century, the mainstream of culture spread was from the east to the west. However, since the middle and late of Ming Dynasty, the situation reversed dramatically. At that time, the economy in western countries developed rapidly and western culture was very active in the world with the Renaissance in Europe. Western culture began to spread to the east rapidly.

Before the Opium War, Chinese culture and western culture communicated with each other based on equality. That is to say, Chinese accepted western learning selectively and still kept Chinese superiority complex in its culture. But after the Opium War, some western countries, depending upon their powerful cannons, forced China to sign a series of unequal treaties of national betrayal and humiliation and opened many treaty ports, which brought about not only the threat of national subjugation, but also great impact on Chinese culture. At the same time, as a mighty culture, western culture marched into China directly and rapidly, which broke China's cultural autonomy and shattered its illusion of self-conceit. From then on, Chinese intellectuals accepted and introduced western learning passively with ignominious feeling. The unprecedented national humiliation made many intellectuals as Zexu Lin, Yuan Wei and Tao Wang and so on to dedicate themselves to the study of western culture. They translated and introduced the knowledge in natural science, social system, etc. They wrote articles to compare the superiority and inferiority of western and Chinese cultures and put forward such a slogan as "Learn advanced technologies from western countries in order to resist the invasion of the western powers" in 
order to explore the way-out for China. They gradually lost confidence in traditional Chinese culture. Some officials launched westernization movement in 1860, by which Qing government utilized new technologies from western countries, established modern military industries, and civilian industries and set up a new navy and land army. The advocates of the westernization movement of the late Qing Dynasty believed that Chinese culture attached more importance to spirit rather than substance, which resulted in its lag in science and technology and that the best way-out was "Chinese learning for the essence, western learning for practical use", that is, traditional Chinese culture was the essential and what Chinese mainly learned from western learning was the advanced and practical technology. Then they set up a new type of schools to teach students western technology and established translation departments to translate western books and journals of technology. Though some achievements were realized, China's situation of accumulated poverty and weakness was not changed essentially. The Northern Fleet was completely annihilated during the war in Weihaiwei, which smashed the advocates' fantasy that the nation could be rich and the army could be strengthened by introducing western military affairs and technology. After that, these Chinese elites made deep introspection and realized that western countries were advanced not only in natural science and in technology, but also in social science such as social and political systems, laws, education and philosophy and so on.

Since then, from the Constitutional Reform and Modernization of 1898 to the Revolution of 1911, Chinese progressive intellectuals instead of missionaries became the main body of spreading western learning and their focus shifted from the physical level to the spiritual level. In addition to western advanced science and technology, they paid more attention to politics-centered humanity and social science and translated many western works in social science into Chinese, which indicated the changes of Chinese elites' viewpoint about western culture and also reflected the process of loss of Chinese cultural confidence.

\subsection{From Insufficient Confidence to Cultural Inferiority}

From the eve of May 4th Movement in 1919 to the foundation of People's Republic of China, many progressive intellectuals, who cared for the fate of China, realized deeply that traditional Chinese culture had much laggard and savage content. They believed that Chinese culture and western culture were different in essence, that is, the former represented decadence, lag, and the latter stood for civilization and progress, which indicated the complete denial of Chinese culture. Many intellectuals began to criticize China's national characteristics. During the May 4th Movement, Duxiu Chen, Xun Lu even made comprehensive criticism on traditional Chinese culture. At that time, almost all influential elites had the same or similar viewpoints about traditional Chinese culture. Even Shuming Liang, who had insisted on praising Chinese culture, had to temporize and pointed out more than ten shortcomings of traditional Chinese culture and national characteristics. They reached a consensus that traditional Chinese culture and national characteristics were the main impediments to prevent China from realizing modernization in due course.

They concluded that learning western technologies was not enough and the only way-out was to learn western culture, which could bring about deep changes in thoughts and make China realize modernization early. Some intellectuals, who were not satisfied with the government, argued that China had to be westernized and that the correct way for China to realize modernization was to construct a new political system and cultural system by resorting to western culture. Chinese people's confidence in their culture collapsed completely. They were not only against the dictatorial system of feudalism, but also cursed Confucian culture, which coexisted with the feudalism system. They even complained that China could not catch up with western countries in science and technology because of its inferior culture, which displayed that Chinese confidence in their culture was completely lost and resulted in cultural inferiority.

During the first 50 years of the $20^{\text {th }}$ century, China was faced with foreign invasions and internal disorder. Internationally, two world wars broke out one after another and Japan launched an invasive war against China in 1937, which lasted for 7 years. At home, situation was not peaceful at all: the Revolution of 1911 overthrew the feudal dynasty, but warlordism appeared; the civil war between communist party and Kuomintang lasted for several years, which made China's social development nearly stagnate. The unstable situation threatened the central position of traditional Chinese culture, which had been marginalized gradually.

\subsection{From Recovery of Cultural Confidence to Its Loss Once More}

Chinese people's confidence in their culture began to recover after the foundation of New China in 1949. China made its own way by combining its own specific conditions with Marxism instead of total westernization. People began to realize that traditional Chinese culture had much essence and that the best way was to take the essence and discard the dregs. Zedong Mao pointed out that traditional Chinese culture should not be denied completely. Under the leadership of Zedong Mao, China made one victory after another, which enhanced people's confidence 
in their culture. However, the Great Cultural Revolution from 1966 to 1976 gave a big blow to traditional Chinese culture and much of excellent traditional culture was rejected and deemed retroactive.

At the beginning of 1980s, China adopted reform and opening policies and opened its door initiatively. With opening to the world and the development of market economy, western values, catering culture and holiday culture had great impact on Chinese culture and even western culture was worshipped blindly in some fields. Many began to criticize traditional Chinese culture from new respects. Then a new wave of denying traditional culture and westernizing totally emerged again accordingly. The thought that all western things were better than Chinese counterparts spread quickly in China. The recovered confidence in culture fell to the bottom again in 1990s. At that time, many Chinese people felt honored to buy and consume foreign products. They prided themselves on their ability of speaking English, and their conversation was larded with some English words frequently on purpose. They imitated the western lifestyle. Western holidays, especially Christmas and Valentine's Day, were very popular with young people while traditional Chinese holidays were ignored. They knew more about western holidays than traditional holidays, which they were even reluctant to know about at all. They considered that celebrating western holidays was fashionable while celebrating traditional holidays was out of date. That is, they believed that everything western was better than Chinese counterpart was.

\subsection{From Cultural Self-consciousness to Persistent Recovery of Confidence in Culture}

China had been copying many things from western countries passively or initiatively for more than one hundred years, which resulted in the loss of Chinese cultural confidence. However, the situation has changed greatly with the prosperity of China since the $21^{\text {st }}$ century. China has made great achievements since the $21^{\text {st }}$ century whereas dilemmas of technology and spiritual crisis brought about by western modernity have become more and more evident. For instance, China hosted 2008 Beijing Olympic Games and Shanghai World Expo (2010) successfully, which greatly enhanced Chinese people's confidence in their culture. Besides, China has developed steadily despite the international financial crisis, which makes the world, especially the western countries look at it with quite different eyes. Some western scholars have begun to reconsider western modernity and think about the success China has made. They are curious about "Chinese model" and trying to find an answer from Chinese culture. They believe that many Chinese cultural elements such as thought of harmony between human and nature and synthetic thinking pattern can make some remedy to western culture. Many Chinese people are also conscious of the superiority of their own culture and confident that China can do what western countries can in Chinese model and even can do what western countries cannot in Chinese model. It is very important for Chinese people to have cultural self-consciousness, which stands for wakefulness of national spirit.

Sinology craze has emerged at home, which indicates that Chinese cultural confidence has recovered. The program named "Lecture Room" produced by CCTV, which is mainly concerned with traditional Chinese culture and Chinese history, has been popular with many Chinese people. Confucius Colleges or schools of Sinology have also been set up in many universities. In addition, a great project on the compiling of "Confucian Collection" and Confucian research was launched in 2004 with the help of Chinese ministry of education. Internationally, since the first Confucius College was established in Seoul, Korea, more than 200 Confucius Colleges have been set up around the world, which promotes Chinese craze and Chinese culture craze.

Nowadays, Chinese people can treat their own culture and western culture properly. On the one hand, they are proud of their own culture. On the other hand, they can accept some good points in western culture. The tolerance of other cultures embodies Chinese confidence in their own culture.

\section{Favorable Conditions for China to Enhance Its Cultural Confidence}

China has had favorable conditions to enhance its cultural confidence. First, China, as one of the four ancient civilizations, is the only existing civilization and it has a history of several thousands of years without interruption, which indicates the vitality of Chinese culture. It looks like an everlasting light and gives Chinese people confidence and pride in their culture. Chinese people are sure that new magnificence of culture will be made based on upholding excellent traditional Chinese culture. Secondly, Chinese culture has become an important part of the world culture, and any values in Chinese culture such as "One should treat others as one would like to be treated.", "self-discipline", "social commitment" etc., which reflect the essential necessities of human being, are accepted by people around the world. Thirdly, good economic conditions provide a solid foundation for China's reconstruction of cultural confidence because economic basis determines superstructure. China, which is now the world's second largest economy, has every confidence to bring its culture in line with its economic status. The great rejuvenation of Chinese nation surely entails the prosperity of Chinese culture, so every effort will be made to improve Chinese citizens' sense of identity and confidence in Chinese culture. 


\section{Measures to Be Taken in Restoring Chinese Cultural Confidence}

\subsection{To Improve Cultural Awareness}

Cultural awareness is the basis and premise of cultural confidence and cultural confidence is the embodiment of cultural awareness. In 1997, Xiaotong Fei first put forward the notion of "cultural awareness". He holds that people in certain culture should have self-knowledge about their culture, that is, to know its origin, the process of its formation, its characteristics and development tendency and that they should be aware of its strengths and weaknesses and know how to carry forward strengths and overcome weaknesses. (Fei, 2005: 344) But many Chinese people know a little about their traditional Chinese culture, which results in the self-doubt and self-denial about their own culture. Their cultural awareness is not adequate due to some historical reasons. Therefore, they should be taught to know about more about their culture, especially about its strengths. In this way, their pride in their culture will be greatly aroused, which will enhance their cultural awareness and cultural confidence accordingly.

\subsection{To Understand and Rethink Traditional Chinese Culture Deeply}

Traditional Chinese culture should be understood and treated in a rational manner to strengthen Chinese people's cultural identity. As the collective memory of Chinese nationality, traditional Chinese culture is the soul of the nation. It is the precious spiritual wealth and treasure for Chinese nationality. It contains the spiritual pursuit and essential spiritual gene of Chinese nationality. However, it is the result created by past generations, which means that except for essence there must be something out of date and against the modern era. That is, there must be some dregs as well. Therefore, Chinese should study and rethink their traditional culture carefully and deeply so that they can inherit the essence of traditional culture and discard those points which are not in line with the present social development.

\subsection{To Deal with the Relationship between Chinese Culture and Western Culture Properly}

Culture is the wisdom of a specific nationality, which reflects the ways in which the nationality deals with things. Each culture has its own strengths, contributes to the world civilization in its unique way and is one part of common spiritual treasure for human being. In a world of high integration and economic globalization, no culture can isolate itself from others and prosper without interacting with other cultures. It is necessary to treat foreign cultures with tolerance and openness and learn from each other to make up for each other's deficiencies. A lesson drawn from Chinese history tells us that self-seclusion may make a nation lose an important opportunity of development. In fact, self-seclusion is the embodiment of cultural diffidence. Of course, another lesson from history should not be forgotten either: total westernization made China lose its cultural confidence completely. Therefore, the best way to treat western culture is to accept those that are useful for Chinese development and try to make them sinicized and localized. Only by taking in the essence of different cultures can Chinese culture be constructed as an advanced and modern one. Meanwhile, Chinese cultural confidence will be boosted in the process of communicating with other cultures.

\section{Conclusion}

Chinese nationality has created excellent culture with a long history. However, it has experienced ups and downs in cultural confidence due to various historical reasons. It is proven by the history that neither cultural conceit nor cultural inferiority is feasible. With the rapid economic development, Chinese nationality is gaining its cultural confidence. It is believed that Chinese nationality can surely add new splendor to Chinese culture based on inheriting and innovating its fine traditional culture. Faced with the impact and challenge brought about by western culture, Chinese nationality should be fully confident in its own culture and take in essence of western culture by making them localized and sinicized, which surely can make Chinese culture full of vitality and spread around the world.

\section{References}

Du, Z. J. (2011). Cultural Inferiority, Cultural Arrogance and Cultural Confidence. Morality and Civilization, 4, $18-23$.

Fei, X. T. (2005). On culture and culture awareness: retrospection and understanding of reconstruction of sociology and anthropology. Beijing: Qunyan Press.

Li, Y. (1998). Rethinking about the Cultural Viewpoint of Total Westernization. Journal of China Youth University for Political Sciences, 2, 64-69.

Liang, M. S. (1989). Eastern culture, western culture and their philosophy. Collected Edition of Liang Mingshu (Vol. 1). Jinan: Shandong People's Press. 
Yang, J. (2010). Cultural Confidence and Cultural Introspection in the Process of Multi-cultural Communication_-Thinking about Shanghai World Expo. Journal of Hubei University of Economics(Humanities and Social Sciences), 7(11), 132-133.

Yu, M. X. (2010). From Cultural Inferiority to Cultural Self-esteem - Thinking about Hu Shi's Total Westernization. Journal of Ningbo University (Liberal Arts Edition ) , 23(1), 52-57.

Yun, S. (2011). Cultural Awareness, Cultural Confidence, Cultural Strength - An Approach for Ensuring the Thriving Development of Socialist Culture with Chinese Characteristics. Journal of Qiushi, 1, 10-39.

Zhong, C. X. (2011). The Power of Cultural Confidence. Journal of Qiushi, 7, 48-49. 